\title{
PENAFSIRAN ABDULLAH IBN ABBAS TERHADAP SURAH AL-FATIHAH
}

\author{
Oleh:
}

\author{
Ahmad Nurul, Aslim Abdullah \\ Asmar Ag, Arifani Febrianti, Muzna Attamimi
}

Email:
Ilmualqurantafsir2019@gmail.com / iat@iainpalu.ac.id

\section{Abstrak:}

Tulisan ini ingin menjelaskan penafsiran Ibnu Abbas menegenai Surat Al-Fatihah dalam kitab Tafsir Tanwïrul Miqbās yang disusun oleh Fairuz Abadi yang merupakan ulama abad pertengahan yang lahir pada tahun 729. Dalam menjelaskan penafsiran Ibn Abbas penulis menggunakan metode library research atau studi kepustakaan untuk menjelasakan metode yang digunakan oleh Ibn Abbas dalam menjelaskan Surat Al-Fatihah. Pembehasan ini pada dasarnya telah dijelaskan beberapa penelitian dan beberapa jurnal diantaranya yaitu karya Hasan Asyari yang menjelaskan Tafsir Ibn Abbas, selain itu Nuri Hayatti dalam skripsinya juga menjelaskan Tafsir Ibn Abbas. Terdapat perbedaan dari dua penelitian ini yaitu dalam tulisan ini penulis hanya membahas tafsir Al-Fatihah.

Kata kunci: Ibn 'Abbās, Alfatihah, Tanwirul Miqbas 
Volume 1, Number 2, Desember 2019: 79-102

\section{Abstract}

This paper would like to explain Ibn Abbas's interpretation of Surah Al-Fatihah in the book of Interpretation of Tanwi rul Miqbā s compiled by Fairuz Abadi who is a medieval scholar born in 729. In explaining the interpretation of Ibn Abbas the author uses the method of library research or library study. to explain the method used by Ibn Abbas in explaining Surah Al-Fatihah. This assent has basically been explained by several studies and several journals including Hasan Asyari's work which explains the Tafsir of Ibn Abbas, besides that Nuri Hayatti in his thesis also explains the Tafsir of Ibn Abbas. There are differences from these two studies, in this paper the author only discusses the interpretation of the Fatihah. 


\section{Pendahuluan}

Alquran secara harfiah berarti "bacaan sempurna" merupakan sebuah nama pilihan Allah yang sangat tepat, karena tiada satu bacaan pun sejak manusia mengenal tulisa-baca sejak lima ribu taun yang lalu dapat menandingi Alquran Al-karim, bacaan sempurna yang mulia. ${ }^{1}$ Alquran adalah kalam Allah yang diturunkan kepada Nabi Muhammad dan membacanya merupakan ibadah. ${ }^{2}$

Mempelajari Alquran akan memperluas pandangan dan pengetahuan. Alquran, sebagaimana yang didefinisikan oleh para pakar, adalah Kalamullah yang diturunkan kepada Nabi Muhammad sebagai mu'jizat (argument kenabian) yang ditulis dalam mushaf dan diriwayatkan dengan mutawatir serta membacanya adalah ibadah. ${ }^{3}$ Ia diturunkan dengan bahasa Arab, sebagaimana firman Allah dalam surah Yusuf (12) ayat $2::^{4}$

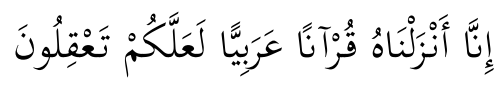

Terjemahnya :

Sesungguhnya Kami menurunkannya berupa Alquran dengan berbahasa Arab, agar kamu memahaminya.

${ }^{1}$ M. Quraish Shihab, Wawasan Alquran (Bandung; Mizan, 1997), h. 3

2 Manna Al-Qaththan Dasar-Dasar Ilmu al-Qur'an, (Jakarta: Ummur Qura, 2017), h..

3 M. Yunan Yusuf, "Metode Penafsiran Al-Qur'an" dalam Jurnal Syamil, Vol: 2 (1), 2014, h. 58

${ }^{4}$ Alquran terjemah Kementrian Agama Republik Indonesia 
Hendaknya orang yang ingin mendalami alquran atau menjadi mufassir harus memahami bahasa arab, dengan cara itulah kita mempelajari suatu hal. Dalam menafsirkan Alquran diperlukan thariqah al-tafsir, yakni metode atau cara dalam menafsirkan Alquran. Ketepatan metode akan menghasilkan ketepatan tafsir. Sebaliknya kesalahan metode akan melahirkan kesalahan tafsir. ${ }^{5}$ Alquran secara teks memang tidak berubah, tetapi penafsiran teks selalu berubah sesuai dengan ruang dan waktu manusia. Karenanya, Alquran selalu membuka diri untuk dianalisis, diintrepretasikan dengan berbagai alat, metode dan pendekatan untuk menguak isi sejatinya. Aneka metode dan tafsir diajukan sebagai jalan untuk membedah makna terdalam Alquran. Kemukjizatan alquran dapat terbukti dengan ketidakmampuan manusia dan jin untuk menyamai atau menandingi gaya bahasa Alquran. Alquran berbeda dengan al-Hadith yang maknanya dari Allah, sementara lafadznya dari Nabi

Kaidah penafsiran Alquran sebagai media instrumen dalam mengkaji serta memahami Alquran secara baik. Keberadaan tafsir Alquran meduduki posisi sentral dalam pengakajian ilmu keislaman. Seseorang akan dihadapakan pada persoalan yang rancu bahkan memuculkan sikap ambiguitas tatkala pembacaannya terhadap pemahaman Alquran tidak dibekali dengan sebuah tafsir atau pengetahuan tentang tafsir. Keunggulan dalam memahami

\footnotetext{
${ }^{5}$ M. Yunan Yusuf, "Metode Penafsiran Al-Qur'an" h. 58.
} 
kaidah tafsir banyak memberikan kontribusi bagi khasanah keilmuan wawasan Alquran. Dengan berbagai bentuk tafsir sedikit banyak telah mewarnai kajian Alquran.

Telah menjadi lazim bahwa penafsiran Alquran telah berlangsung sejak zaman Nabi Muhammad hingga sekarang, bahkan juga pada masa mendatang. Realitas sejarah membuktikan bahwa penafsiran kaum Muslim terhadap kitab sucinya selalu berkembang seiring dengan perkembangan peradaban dan budaya manusia. Hal ini karena seorang penafsir senantiasa berupaya untuk memikirkan dan menemukan makna dan pesan yang belum bisa dipahami dari teks ayat-ayat Alquran. Namun kemampuan seorang penafsir ini hanya bisa sampai pada derajat pemahaman relatif dan tidak bisa mencapai derajat absolut. ${ }^{6}$

Historisitas tafsir Alquran sejatinya dimulai dengan menafsirkan ayat-ayat Alquran berdasarkan hadis Nabi pendapat sahabat dan tabi'in. Penafsiran semacam ini berkembang dengan pesat, sehingga disadari ataupun tidak, hadis shahih bercampur dengan israiliyyat. ${ }^{7}$

6 Eko Zulfikar, Makna Ulu al-Albab Dalam al-Qur'an: Analisis Semantik Toshihiko Izutsu, dalam Jurnal Theologia, Vol 29, No 1, Juni 2018, h.. 110 .

7 Eko Zulfikar, Historisitas Perkembangan Tafsir Pada Masa Kemunduran Islam: Abad Kesembilan Dan Kesepuluh Hijriah, Dalam Jurnal Tribakti: Jurnal Pemikiran Keislaman Vol 30, Nomor 2, Juli 2019, h. 276. 


\section{Profil Singkat Ibn Abbas dan Fairuz Abadi}

\section{Abdullah Ibn 'Abbas}

Nama 'Abdullah Ibn 'Abbas tidak dapat ditinggalkan ketika seseorang membicarakan tafsir Alquran. Di dalam dunia tafsir, Ibn 'Abbās dianggap "the real father of the science of Tafsir". Laporan terkait dari Ibn 'Abbas mengenai tafsir Alquran sangat melimpah. Bahkan hampir tidak ada ayat Alquran yang tidak dikaitkan dengan penafsiran Ibn 'Abbas. Selain karena Ibn 'Abbās termasuk sahabat yang masih hidup pada zaman dimana wilayah Islam sudah meluas dan kebutuhan tafsir ayat-ayat Alquran semakin meningkat, ia juga yang secara langsung mendapatkan doa khusus dari Nabi dinyatakan bahwa Ibn 'Abbās-lah yang mendapat legitimasi langsung dari Nabi menjadi salah seorang yang mampu memahami dan menafsirkan Alquran dengan doa khusus dari Nabi

$$
\text { اللهم فقهّه فن الدين و علّمه التأويل }
$$

"Ya Allah, anugerahilah dia pemahaman dalam agama dan ajarlah dia penafsiran (Alquran). ${ }^{8,}$

Nama lengkap Ibn 'Abbās adalah Abdullah Bin bin Abbās bin Abdul Muthalib bin Hasyim bin Abdul Manaf Al-Quraisiy AlHasyimi, sepupu Rasulullah Ibunya adalah Ummul Fadhl

${ }^{8}$ Tribakti: Jurnal Pemikiran Keislaman Volume 30, Nomor 2, Juli 2019,h.. 275. 
Lubabah binti Harits Al-Hilaliyah. Ibn 'Abbas lahir ketika bin Hasyim berada di pedusunan, tepatnya tiga tahun sebelum hijrah ${ }^{9}$, yakni pada masa pemboikotan suku Quraisy terhadap keluarga Nabi dan yang mendukungnya (Bani Hasyim dan Bani Muthallib). ${ }^{10}$

Abdullah bin 'Abbas diberi gelar lautan ilmu pada masanya. ${ }^{11}$ Ibn 'Abbas dalam memhami makna kata-kata Alquran banyak merujuk pada sya'ir-sya'ir arab,karena beliau memiliki penetahuan yang mempuni tentang seluk beluk bahasa dan sastra arrab kuno. ${ }^{12}$

\section{Fairuzabadi}

Al-Fairusabadi, Nama lengkapnya adalah Muhammad bin Ya'qub bin Muhammad bin Ibrahim bin Muhammad bin Abi Bakr bin Idris ibn Fadl Allah bin al-Shaikh Abi Ishaq Sahib pengarang kitab “al- Tanbih" al-Shaikh Majd al-Din Abu al-Tahir al-Shairazi al-Fairuzabadi Shahib "al-Qamus. Al-Fairuzabadi lahir pada Rabi” al-akhir, ada yang menyatakan Jumad al-Akhir tahun 729 di Kazrun sebuah kota di Persi antara al-Bahr dan Shairaz. Ia tumbuh

${ }^{9}$ Manna' Al-Qaththan, Dasar-Dasar Ilmu al-Qur'an, (Jakarta: Ummur Qura, 2017),h. 568.

10 Tribakti: Jurnal Pemikiran Keislaman Volume 30, Nomor 2, Juli 2019, h.. 276.

${ }^{11}$ Muhammad bi Ismail Al-Amri Ash-Shan'ani, Subulus Salam, terj, Muhammad Isnaini, dkk, (jalarta; Durus Sunnah press 2017), h. 19.

12 Ali Mufron, pengatar Ilmu Tafsir dan Quran, (yogyakartau; Aura Pustaka 2014),H.. 323. 
dan menghafal Qur'an pada saat berada di Kazrun tersebut, saat umur 7 tahun ia menghafal al-Qur'an.

Kemudian setelah pindah ke Shairaz, ia belajar bahasa serta adab dari ayahnya sendiri di samping kepada Qawam al-Dīn 'Abd Allah bin Mahmud dan lainnya. Selanjutnya ia ke Baghdad, dan di kota ini ia belajar kepada Taj al-Dīn Muhammad bin al-Sabbak, kemudian menuju Damaskus, ia belajar kepada lebih dari 100 guru, selanjutnya ke Quds yang membawanya kepada kemasyhuran, karena di kota inilah ia mulai mengajar dan menerbitkan karyakaryanya. Kemudian dilanjutkan ke Kaero dan belajar kepada al- Jamal al-Asnawi, Ibn Hisham, al- Baha' bin 'Uqail dan beberapa ulama lain. Perjalanan ilmiah al- Fairuzabadi ini berlangsung terus hingga mencapai wilayah Tenggara menuju Roma, India dan beberapa kota lainnya ${ }^{13}$.

\section{Sistematikan Tafsir Tanwir al-Miqbas}

Dalam menjelaskan tasfir ini penulis juga menjelaskan sistematikan yang digunakan oleh Fairuz Abadi dalam menyusun Tafsir Ibn Abbas, Adapun sistematikanya yang digunkaan dalam tafsir ini yaitu

Pertama, Sumber penafsiran dalam sumber penafsiran yang digunakan oleh al-Fairuzabadi dalam penulisan kitab ini adalah

${ }^{13}$ A. Hasan Asy' Ari Ulama'I, jurnal; Tanwir Al-Miqbas min Tafsir ibn Abbas karya Fairus Abadi, (Wahana Akademika vol 6,No. 2, 2004). 146. 
menggunakan metode tafsir bi al-ma'tsur dengan pendapat Ibn 'Abbas sebagai 'sumber' rujukan penafsiran utama. Selain itu, Ibn 'Abbas juga menggunakan syair-syair Arab kuno sebagai sarana penunjang yang membantu pemahaman makna lafadz yang gharib dari Alquran. Ibn 'Abbas menyatakan, "Bila kalian bertanya kepadaku tentang lafadz yang gharib dalam Alquran, carilah keterangannya dari syair-syair Arab kuno, karena syair Arab kuno merupakan sumber rujukan bahasa Arab (diwan al-'Arab)." Di samping itu, Ibn 'Abbas juga merujuk kepada ahlu al-kitab yang sesuai dengan kandungan dan ajaran Alquran.

Kedua dalam susunan dan tertib surat tafsir ini ini hanya terdiri dari satu jilid dengan 600 halaman. Namun sasaran dan tertib ayat yang ditafsirkan dimulai dari surat al-Fatihah dan berakhir dengan penafsiran surat al-Nas. Sehingga penafsiran yang dimulai dari awal hingga akhir merupakan ciri dari tafsir tahlili.

Ketiga, cara penjelasan tafsir Tanwir al-Miqbas sangat global sehingga memudahkan pembaca sekaligus membiarkan pembaca mengembangkan sendiri seluas-luasnya pemahaman terhadap Alquran. Berdasarkan ini, maka kitab tafsir ini masuk dalam kategori penjelasan ijmāli.

Selanjutnya Fairus Abadi juga menjelaskan bahwa dalam menjelaskan ayat-ayat al-Qur'an Ibn 'Abbās juga menggunakan ijtihad dalam menafsirkan ayat. Ia memiliki kecenderungan untuk menggunakan akal pikiran yang jernih dalam menafsirkan ayat 
Alquran. Ia juga tidak monoton menggunakan standar baku penafsiran ayat dengan ayat lainnya, atau ayat dengan hadis Nabi . Ibn 'Abbās berani berijtihad dan diakui oleh kalangan para sahabat. Sebagai contoh representatif tafsirnya adalah ketika Ibn Umar meminta Ibn 'Abbās untuk menafsirkan QS. al-Anbiya [21]: $30^{14}$

\section{Penafsiran Al-Fatihah Dalam Tafsir Ibn Abbas}

Surah al-Fatihah merupakan surah madaniyyah dan ada yang berpendapat bahwa al-Fatihah merupakan surah Makiyyah, diturunkan setelah surah al-Mudatstir.

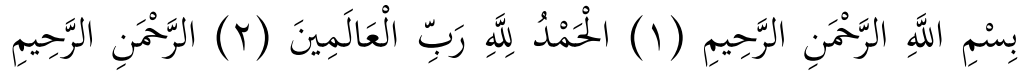

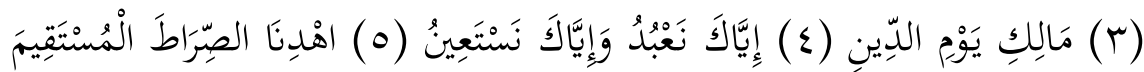

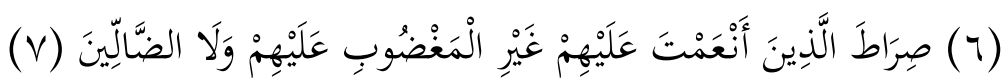

Disandarkan kepada Ibn 'Abbās, mengenai firman Allah 뜬 beliau mengatakan : bersyukur kepada Allah merupakan perbuatan (kewajiban) makhluk-Nya dengan cara memuji-Nya, dikatakan: bersyukur kepada Allah atas segala nikmat-Nya yang sempurna kepada hamba-Nya, yaitu orang-orang yang diberi petunjuk dengan iman, dikatakan pula: kesyukuran, ketauhidan,

14 Eko Zulfikar, Historitas Perkembangan Tafsir Pada Masa Kemunduran Islam, abat Kesembilan dan Sepuluh Hijriayah dalam Jurnal Tafsir Vol 30, No. 2, 2019, 290. 
dan ketuhanan hanya milik Allah, yang tidak beranak, dan juga tidak ada sekutu bagi-Nya, tidak rendah (hina), dan juga tidak memiliki pengganti. (رب العلمين ) tuhan seluruh makhluk yang bernyawa yang ada dimuka bumi dan di langit, dan dikatakan pula pemimpin jin dan manusia, dan dikatakan yang menciptakan makhluk serta memberi rezeki dalam keadaan apapun. (الرحمن ) maha lembut yaitu belas kasih, ( الرحيم) yang halus dan ramah, ( sang hakim pada hari pembalasan yaitu yaumul hisab dan memberi keputusan diantara makhluk-makhlukNya, atau hari pembalasan bagi manusia sesuai amal mereka dan tidak ada hakim selainNya. ( إيّاك نعبد ) kami mengesahkanmu dan menaatimu, ( و إياك ) (نستعين kami memintanta pertolongan kepadamu dalam ibadah kepadamu dan hanya kepadamu kami mencari kepastian atas ketaatan kepadamu, ( إهنا الصر اط المستقيم ) tunjukilah kami agama yang lurus yang engkau ridhoi yaitu islam, dan dikatakan: tetapkanlah bagi kami agama islam, dan dikatakan: Alquran, Ibn 'Abbās berkata: tunjukilah bagi kami yang halal dan haram dan penjelasan apa yang di dalamnya, ( صراط الذين انعمت عليهم ) agama orang-orang yang engkau keruniai yaitu pengikut nabi Musa, sebelum engkau menetapkan bagi mereka yaitu nikmat Allah, sebagaimana awan menaungi mereka dan Allah menurunkan kepada mereka mannā dan salwa, dan dikatakan: mereka adalah para Nabi ( غير المغضوب عليهخ ) bukan agama Yahudi yang engkau murkai, engkau membiarkan mereka dan tidak menjaga hati mereka sehingga mereka menjadi yahudi, (و لا الضالّين ) dan bukan 
agama Nasrani yang tersesat dari Islam ( آمين ) demikian engkau jadikan kepercayaannya, dan dikatakan hendaklah demikian, dikatakan: ya tuhan kami tetapkan bagi kami sebagaiman permintaan kami kepadamu, wallahu 'alam.

\section{Analisis Penulis Terhadap Hasil Penafsiran Ibn Abbas}

Jika seorang hamba mengaku beriman kepada Allah hendaklah ia selalu bersyukur atas nikmat Allah yang diberikan kepadanya dengan memuji kebesaran-Nya dan menjadikan Allah sebagai zat yang berhak di sembah. Dan Allah adalah tuhan seluruh makhluk, pemimpinnya alam semesta,dan yang menciptakan segala sesuatu serta menjamin rezeki makhluk-Nya kerena sifat yang pengasih serta penyayang.

Tidak ada tempat untuk meminta selain Allah karena Allah 斱 pemilik segalanya tidak ada yng lepas dari pengawasan Allah. Perlu di ketahui bahwa akan adanya hari akhir dan kita harus mempersiapkan itu.

Kita semua diberi kebebasan untuk melakukan sesuka hati tetapi pada hari kemudian kita akan dimintai pertanggung-jawaban atas yang telah kita perbuat, apabila amal kita baik maka kita akan merasa aman, oleh karena itu hendaklah menyemba dan meminta patutnya hanya kepada Allah dengan sifat-Nya Ar-Rahim, setelah itu patutlah kita meminta petunjuk kepada-Nya agar jalan hidup kita menjadi indah yang perpedoman kepada syari'at agama Allah. 


\section{Komentar Ulama tentang Kitab Tanwir al-Miqbas}

Abdullah ibn Abbas dikenal dengan tokoh yang banyak riwayat-riwayatkan kepadanya, bahkan hampir disetiap ayat, ditemukan riwayat-riwayat itu dinisbatkan kepada ibn 'Abbas ra. Padahal banyak sekali dari riwayat itu yang palsu. Sehingga tidak dapat dijadikan kitab rujukan. ${ }^{15}$

Kehati-hatian menyangkut riwayat-riwayat perlu ditegakkan tanpa mengabaikan yang sahih. Salah satu kritik yang ditujukan kepada syekh Muhammad Abduh adalah kehatihatiannya yang amat berlebih terhadap sunnah, sampai-sampai amat terkesan bahwa ulama pembaru itu hanya menjadikan Alquran sebagai sumber hukum satu-satunya di tambah dengan sedikit sunnah amaliah. ${ }^{16}$

\section{Metodologi Periwayatan Dalam Kitab Tanwir al-Miqbas}

Dalam bagian ini penulis akan menjelaskan periwayatan yang digunakan oleh Ibn Abbas dalam Kitab Tafsir Tanwir alMiqbas. Berdasarkan hasil penelusuran penulis Tafsir ini mempunyai dua jalur periwayatan, yaitu ${ }^{17}$ :

15 M. Quraish Shihab, Kaidah Tasfir,(Tangerang; lentera hati, 2019),H.. 303.

16 M. Quraish Shihab, Kaidah Tasfir,(Tangerang; lentera hati, 2019),H.. 304.

${ }^{17}$ Hasan Su'aidi, Kualitas Hadits Dalam Kitab Tafsir Tanwir AlMiqbas Min Tafsir Ibni Abbas (Kritik Sanad Hadits) Dalam Jurnal Religia Vol. 18 No. 1, April 2015,h.. 29-30. 
Pertama, Abdullah ats-Tsiqah bin al-Ma'mun al-Harawi, al-Ma'mun alHarawi, Abu Abdillah Mahmud bin Muhammad arRazi, Ammar bin Abdul Majid al-Harawi, Ali bin Ishaq asSamarqandi dari Muhammad bin Marwan, Muhammad bin asSaib al-Kalbi, Abu Shalih, Abdullah bin Abbas.

Kedua Abdullah bin Mubarak, Ali bin Ishaq asSamarqandi, Muhammad bin Marwan al-Kalbi, Abu Shalih, Abdullah bin Abbas, Berikut contoh penggunaan sanad dalam kitab tafsir Tanwir Miqbas min Tafsir Ibni 'Abbas: Contoh Sanad Pertama

$$
\begin{aligned}
& \text { وصلى الله لب سيدنا محمد وا أجمعين أخبرنا عبد الله اكخقة ابن المأمور } \\
& \text { الهروى قال اخبرنا أبى قال أخبرنا أبو عبد الله قال أخبرنا أبو عبيد الله محمود } \\
& \text { بن محمد الرازى قال أخبرنا عمار بن عبد المجيد الهروى قال أخبرنا على بن } \\
& \text { اسخق السمرقندى عن محمد بن مروان الكلبى عن أبى صالح عن ابن عباس. }
\end{aligned}
$$

Sanad di atas disebutkan dalam menafsirkan ayat pertama surat al-Fatihah (bismillahirrahmanirrahim), kemudian untuk menafsirkan ayat selanjutnya, al-Fairuzabadi mengawalinya dengan pernyataan

$$
\text { و بإسناده عن ابن عباس فى قو تعالى (الله الحمد) يقول الشكر الله وهو ان }
$$


Contoh sanad kedua

$$
\begin{aligned}
& \text { و بإسناده عن عبد الله بن المبارك قال حدثنا على بن اسحق السمرقندى عن } \\
& \text { محمدبن مروان الكلى عن أبى صالح عن ابن عباس فى قو تعالى ( ألم ) يقول }
\end{aligned}
$$

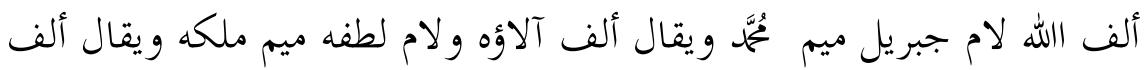

$$
\begin{aligned}
& \text { إبتداء إسمه الله لام إبتداء إسمه لطيف ميم ابتداء إسمه مجيد ويقال انا الله } \\
& \text { أعلم ويقال قسم أقسم به إلى آخره ..... }
\end{aligned}
$$

Dari dua sanad di atas, sanad kedua hanya disebutkan oleh al-Fairuzabadi dalam penafsiran surat al-Baqarah. Selanjutnya, dalam mengawali setiap penafsiran surat-surat lainnya, alFairuzabadi hanya menyebutkan "Wa bi Isnādihi An Ibni "Abbās" (dari sanad yang bersumber dari Ibnu Abbas), tidak ada penyebutan sanad selain dari sanad yang telah disebutkan pada surat al-Fatihah.

Untuk mengetahui kualitas sanad diperlukan telaah dan analisis dengan menggunakan kaedah dan tolok ukur (Mi'yar) kesahihan sanad hadits. Dalam operasionalnya, analisis terhadap sanad diawali dengan penelusuran biografi masing-masing perawi melalui kitab-kitab rijal al-Hadith. Selanjutnya melakukan analisis terhadap kualitas masing-masing perawi melalui kitab-kitab alJarh wa at-Ta'dil. Dari dua langkah penelitian tersebut, dapat 
diketahui aspek-aspek yang harus terpenuhi oleh sanad hadits yang shahih di atas. ${ }^{18}$

Adapun model dan contoh penafsiran Ibn 'Abbās secara global, khususnya yang telah disalin dan dihimpun oleh alFairuzabadi dalam kitab Tanwïr al-Miqbas min Tafsir Ibn 'Abbās adalah sebagai berikut: ${ }^{19}$

1. Format umum pada setiap awal surat, dalam hal ini alFairuzabadi mengawali penafsirannya dengan ungkapan sebagai berikut: wa bi isnādihi 'an Ibn 'Abbās. Artinya, penafsiran ayat-ayat yang akan ia sampaikan tersebut disandarkan kepada sanad yang telah tertera dalam muqaddimah tafsir, yaitu riwayat 'Abd Allah al-Siqah bin alMa'mun al-Harawi, dari al-Ma'mun, dari Abu 'Abd Allah, dari Abu 'Ubaid Allah Mahmud bin Muhammad al-Razi, dari 'Ammar bin 'Abd al-Majid alHarawi, dari 'Ali bin Ishaq alSamarqandi, dari Muhammad bin Marwan, dari al-Kalbi, dari Abu Shalih, dari Ibn 'Abbas. Jalur inilah yang dijadikan sandaran pokok al-Fairuzabadi menafsirkan ayat.

2. Pada surat tertentu, penafsiran Fairuzabadi disandarkan kepada jalur periwayatan yang sedikit berbeda dari jalur

${ }^{18}$ Hasan Su'aidi, Kualitas Hadits Dalam Kitab Tafsir Tanwir AlMiqbas Min Tafsir Ibni Abbas (Kritik Sanad Hadits) dalam Jurnal Religia Vol. 18 No. 1, April 2015. h. 29-30

19 A. Hasan Asy'ari Ulama'i, Tanwir Al-Miqbas Min Tafsir Ibn 'Abbas Karya Al-Fairuzabadi, Dalam Jurnal Wahana Akademika, Vol. 6, Nomor 2, September 2004, h. 150-152. 
periwayatan yang pokok (poin no 1). Contoh: pada saat mengawali tafsir surat al-Baqarah, al-Fairuzabadi menggunakan sandaran riwayat sebagai berikut: wa bi isnadihi 'an 'Abd Allah bin al-Mubarak qala haddasana 'Ali bin Ishaq alSamarqandi 'an Muhammad bin Marwan 'an alKalbi 'an Abi Salih 'an Ibn 'Abbas. Artinya, penaf-siran ayatayat dalam surat al-Baqarah ini disandarkan pada riwayat 'Abd Allah al-Siqah bin al-Ma'mun al-Harawi, dari alMa'mun, dari Abu 'Abd Allah, dari Abu 'Ubaid Allah Mahmud bin Muhammad al-Razi, dari 'Abd Allah bin alMubarak (pada jalur pokok diriwayatkan 'Ammar bin 'Abd alMajid alHarawi), dari 'Ali bin Ishaq alSamarqandi, dari Muhammad bin Marwan, dari al-Kalbi, dari Abu Shalih, dari Ibn 'Abbas.

3. Penyandaran riwayat dalam setiap surat di atas (point 1 dan 2) merupakan upaya alFairuzabadi menafsirkan Alquran sesuai dengan riwayat Ibn 'Abbas. Namun demikian, ada beberapa penafsiran alFairuzabadi dalam kitab Tanwir al-Miqbas ini yang tidak diriwayatkan Ibn 'Abbās. Contoh: Penafsiran kata "wa shahidin wa mashhud" (Qs alBuruj) dengan makna "hari Jumah dan hari Arafah”. Penafsiran tersebut setelah dilakukan penelusuran kepada kitab Jami al-Usul fi Ahadis alRasul karya Ibn al-Asir merupakan riwayat Abu Hurairah. Contoh lainnya adalah penafsiran kata "tabaqan an tabaq" (Qs alInsyiqaa: 19) yang diartikan sebagai halan bạda halin (keadaan 
demi keadaan yaitu kematian kemudian kehidupan, kematian kemudian kehidupan lagi dan seterusnya). Penafsiran ini merupakan riwayat Ibn Umar dan bukan riwayat Ibn 'Abbās.

4. Bahkan tak jarang riwayat Ibn 'Abbās yang terdapat di dalam kitab Jami“ al-Usul (sebagai kitab himpunan dari kitab-kitab hadis mu'tabar, seperti Sahih al-Bukhari, Sahih Muslim, Sunan al-Tirmizi, Sunan Abi Dawud, dan beberapa kitab hadis lain) tidak dimasukkan dalam kitab penafsiran al-Fairuzabadi ini. Contoh: kalimat "inni mutawaffika" Ibn "Abbās menafsirkannya dengan "mumituka" sebagaimana diriwayatkan al-Bukhari.

5. Termasuk dalam hal Qira'at riwayat Ibn 'Abbās, oleh alFairuzabadi tidak disinggung sama sekali, seperti bacaan tambahan Ibn 'Abbas pada surat al-Baqarah ayat 19: laisa 'alaikum junahun an tabtaghu fadlan min rabbikum fi mawasim al-hajj, di mana kata fi mawasim al-hajj merupakan tambahan dari Ibn 'Abbas. Demikian juga lafad alsalama dipendekkan lam fathahnya dalam surat al-Nisa' ayat 90, dibaca al-salam dengan dipanjangkan lam fathahnya: wala taqulu liman alqa ilaikumus salama lasta mu'mina, qara'a Ibn Abbas al-salama (Riwayat Bukhari dan Muslim).

6. Pada setiap awal surat diberikan keterangan makiyyah madaniyahnya, kemudian jumlah ayat serta jumlah hurufnya.

7. Ditinjau dari metode yang digunakan di dalamnya, tafsir ini menggunakan manhaj (metode) ijmali atau global method, 
mengingat penafsiran dilakukan kalimat-perkalimat, ayat-per ayat, surat-persurat secara berurutan dari awal surat hingga akhir surat dengan tafsiran global atau thariqah al-mujmal. Bahkan kalau boleh dinyatakan, tafsir ini mirip polanya dengan Jalalain yaitu mencari makna padanan, apakah padanan itu diambil dari bahasa ataukan riwayah. Tentunya al-Fairuzabadi bermaksud hanya mencarikannya dari riwayat khususnya kepada Ibn 'Abbas, sesuai dengan penamaan kitabnya Tanwir al-Miqbas min Tafsir Ibn 'Abbas.

8. Ditinjau dari sisi al-laun (warna) tafsirnya, sulit ditentukan secara pasti, mengingat orientasi dan wacana mufassirnya kurang begitu nampak, hal ini dikarenakan orientasi awal dari alFairuzabadi dalam tafsirnya ini adalah menyandarkan pada riwayat Ibn 'Abbas, bukan hendak mengedepankan sisi kebahasaannya, ayat hukumnya, nilai filosofisnya, ilmu kalamnya, sejarahnya, tasawwufnya ataupun yang lainnya.

9. Pada penafsiran ayat tertentu yang menunjuk kepada seseorang atau kelompok orang, Ibn 'Abbas menunjuk nama orang yang ada pada masanya. Contoh: tafsir ayat "wa bil akhirati hum yuqinun" (Qs 2: 4): "dan terhadap hari kebangkitan setelah kematian serta kenikmatan surga mereka meyakininya, yang di maksud mereka ini adalah 'Abd Allah bin Salam wa ashabih" (nama ini sering disebut di samping nama Abu Bakar untuk mewakili orang yang beriman). Sebaliknya, untuk menggambarkan orang yang inkar dari 
kalangan Yahudi, Ibn 'Abbas sering menyebut nama Ka'ab bin Ashraf dan teman-temannya; dan untuk menggambarkan orang yang ingkar dari kalangan musyrikin, Ibn 'Abbās menyebut nama 'Utbah, Shaibah dan Walid. Contoh: tafsir ayat "wa lahum 'azabun 'adim”(Qs 2: 7): "bagi mereka siksa yang pedih, mereka ini orang-orang Yahudi yaitu Ka'ab bin al-Ashraf dan temantemannya, juga mereka ini adalah kelompok musyrik penduduk Mekah seperti 'Utbah, Shaibah dan Walid".

10. Kitab Tanwir al-Miqbas ini, disamping memuat penafsiran

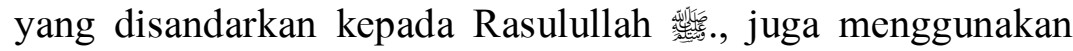
ijtihad atau renungan mendalam Ibn 'Abbas, bahkan beberapa penafsirannya ia sandarkan kepada cerita ahl alKitab. Contoh : Tafsir ayat "qulna ihbitu minha jami'an" (Qs 2: 38) : "Kami berkata kepada Adam, Hawa, ular, burung dan iblis: keluarlah kalian semua dari langit".

11. Mashadir atau sumber penafsiran Ibn 'Abbas lainnya adalah pada syair-syair kuno. Contoh: Tafsir kata "al-wasilah" dalam Qs 5: 35 ditafsirkan dengan "derajat yang tinggi atau jalan terdekat yaitu dengan amal shalih". Dalam kutipan al-Zahabi terhadap penafsiran ayat di atas, Ibn 'Abbas menyertakan sebuah syair untuk memperjelas makna, yaitu: Inna al-rijala lahum ilaika wasilah an ya'khuzuka takhaly wa takhdaby, "Sesungguhnya para pria memiliki hajat kepadamu, bila mereka menghendakimu maka kamu bercelak dan memakai 
warna-warni." Namun dalam Tanwir al-Miqbas, syair ini tidak dikemukakan.

\section{Kesimpulan}

Ibnu Abbas merupakan sahabat Rasulullah yang hampir semua hidupnya bersama Rasullullah. Ibnu Abbas memiliki tafsir yang diberi nama Tanwir miqbas yang disusun oleh Fairuzabadi tetapi ada beberapa permasalahan yang terdapat mengenai periwayat-periwayat yang terdepat dalam tanwirul miqbas. Tapi Quraish Shihab tidak sependapat dengan dengan Abduh, namun sikap kehati-hatian sangat dibutuhkan. Kehati-hatian yang tidak hanya tertuju kepada aneka pendapat pendahulu, tetapi juga aneka pendapat masa kini.

Sebagai contoh penulis mengambil contoh penafsiran AlFatihah yang dijelaskan secara global dengan menjelaskan beberapa riwayatnya secara singkat dan sifatnya umum. Meskipun penafsiran Ibn Abbas menggunakan riwayat, akan tetapi Ibn Abbas tidak melepaskan aspek kebahasaannya, sehingga penafsiran Ibn Abbas juga bisa dikategorikan juga mempunyai corak kebahasaan. Menurut penulis Fairuz Abadi telah berhasil memberikan gambaran secara komprehensif mengenai penafiran Ibn Abbas. 


\section{DAFTAR PUSTAKA}

Alquran terjemahan Kementrian Agama Republik Indonesia

A.Hasan Asy'ari Ulama'i,Tanwir Al-Miqbas Min Tafsir Ibn 'Abbas Karya Al-Fairuzabadi dalam Jurnal Wahana Akademika, Vol. 6, Nomor 2, September 2004.

M. Quraish Shihab, Wawasan Alquran (Bandung; Mizan, 1997).

M. Quraish Shihab, Kaidah Tasfir,(Tangerang; lentera hati, 2019).

M. Yunan Yusuf, "Metode Penafsiran Al-Qur'an" , (Syamil, Volume 2 (1), 2014).

Eko Zulfikar, Makna Ulu al-Albab Dalam al-Qur'an: Analisis Semantik Toshihiko Izutsu, dalam Jurnal Theologia, Vol 29, No 1, Juni 2018.

Hasan Su'aidi, Kualitas Hadits Dalam Kitab Tafsir Tanwir alMiqbas Min Tafsir Ibnu Abbas (kritik sanad hadits) dalam Jurnal Religia vol. 18 no. 1, april 2015.

Manna' Al-Qaththan, Dasar-Dasar Ilmu al-Qur'an, (Jakarta: Ummur Qura, 2017.

Al-Hafiz Shams al-Din Muhammad bin 'Ali Ibn Ahmad alDawudi, Tabaqat al-Mufassirin, (ttp: Maktabah Wahbah Abidin, 1992), juz 2.

Eko Zulfikar, Historisitas Perkembangan Tafsir Pada Masa Kemunduran Islam: Abad Kesembilan Dan Kesepuluh Hijriah, Tribakti: Jurnal Pemikiran Keislaman Volume 30, Nomor 2, Juli 2019. 
Ahmad, dkk, Penafsiran Abdullah Ibn Abbas.....

Muhammad bi Ismail Al-Amri Ash-Shan'ani, Subulus Salam, terj, Muhammad Isnaini, dkk, (jakarta; Durus Sunnah press 2017. 